\title{
Co pacjenci mogą robić z tabletkami? Studium przypadku osób cierpiących na zaburzenia lękowe
}

\section{Abstract \\ What the Sufferers Can do with the Medicines? Case Study of the People with Anxiety Disorders}

The aim of the article is to analyze the practices that Polish patients (suffering from anxiety disorders) can perform with the pills, prescribed by psychiatrists. There are three main practices which are highlighted in the article: manipulating the dosage and frequency of consumed drugs, deciding which medicines will be consumed and keeping the drugs at home without consumption. In a broader sense, they can be understood as a form of resistance against biomedicine (Clarke et al. 2010: 14) and form of Robert Merton's self-fullfilling prophecy. The mentioned practices are connected with the opinions about pharmacotherapy shared by my interlocutors.

Keywords: pharmacotherapy, medical anthropology, anxiety disorders, biomedicine.

Trudno tak naprawdę wskazać dziedzinę medycyny, która obywała by się bez, mniej lub dalej posuniętej, interwencji farmakologicznej. Jeżeli chodzi o leczenie zaburzeń psychicznych, to farmakoterapia od połowy XX wieku zaczęła zastępować metodę leczenia za pomocą elektrowstrząsów (Pużyński 1997: 165). W ciągu kolejnych lat katalog dostępnych leków psychotropowych znacznie się rozszerzył, oferując coraz lepiej działające medyczne środki. Są to leki dostępne wyłącznie na receptę, którą może wystawić psychiatra lub też inny lekarz, nie posiadający specjalizacji z zakresu psychiatrii (np. lekarz kardiolog, specjalista chirurgii ogólnej, 
specjalista chorób wewnętrznych). Ich pojawienie się i stopniowe powstawanie kolejnych odmian takich medykamentów odcisnęło piętno na medycynie: $\mathrm{w}$ ramach psychiatrii powstał „biomedyczny model” leczenia zaburzeń psychicznych, który odsuwał na dalszy plan społeczne czynniki, zarówno wywołujące, jak i pomagające $\mathrm{w}$ uśmierzaniu zaburzeń, wprowadzając postrzeganie tych ostatnich jako spowodowanych przede wszystkim „wewnętrznymi mechanizmami” organizmu, na które to mechanizmy można oddziaływać środkami farmakologicznymi, doprowadzając tym samym do eliminacji zaburzeń (Cohen 1993: 516; por. Metzl 2003). Niektórzy badacze alarmują, że we współczesnych społeczeństwach zachodnich gwałtownie wzrasta konsumpcja wymienionych kategorii medykamentów - co wiązane jest ze znaczeniem i aktywnością koncernów farmaceutycznych, a także ze zjawiskiem postępującej „psychiatryzacji kondycji ludzkiej” (Rose 2006; zob. Nowakowski 2013; Conrad 2005; Wróblewski 2013; analiza kulturowej opowieści o cudownym oddziaływaniu Prozaku: Wasilewski, Wasilewska 2006). W ramach owej „psychiatryzacji” miałaby mieć miejsce medykalizacja na przykład nieśmiałości czy lęku przed innymi ludźmi, na które współczesna psychiatria byłaby w stanie zaoferować medyczne panaceum w postaci tabletki, identyfikując wspomniane przypadłości jako zaburzenia wyleczalne odpowiednimi medykamentami (Conrad 2005; Nowakowski 2013: 119-214). Dyskurs zbudowany wokół konsumpcji leków antydepresyjnych może również szafować obietnicą reintegracji społecznej (opuszczenia przestrzeni marginesu) osób chorych na depresję - reintegracji, która przebiegałaby poprzez poddanie się leczeniu farmakologicznemu (Ecks 2005: 241). Tym samym farmakoterapia mogłaby oddziaływać nie tylko na zdrowie, ale także na trajektorie biograficzne pacjentów. W USA nowe leki antydepresyjne, takie jak Prozac, Zoloft czy Paxil, „sprawiły, że terapia farmakologiczna zaczęła być traktowana raczej jako narzędzie poprawiające wydajność, a nie jako forma leczenia" (Wróblewski 2013: 71; por. Clarke et al. 2003: 181; Wasilewski, Wasilewska 2006), a zatem środki mogące działać na rzecz awansu społecznego osób je biorących (np. eliminując stres, który może zaburzać efektywność pracy i tym samym oddziaływać na przebieg kariery zawodowej). Wzrost konsumpcji leków psychotropowych, na który zwrócił uwagę m.in. Nikolas Rose, wiązać można $\mathrm{z}$ procesem biomedykalizacji - a więc napędzanym dzięki osiągnięciom nauki (Clarke et al. 2003: 162) procesem coraz szerszych i bardziej zaawansowanych medycznych „interwencji w życie człowieka” (Clarke et al. 2003: 170). Takie interwencje mogą następować między innymi w drodze układanej przez psychiatrów kuracji farmakologicznej. Pojawienie się nowych leków psychotropowych, jak preparaty oparte na escitalopramie (substancja czynna), a także leków benzodiazepinowych (o działaniu uspokajającym $)^{1}$, zawierających substancję czynną alprazolam (Xanax, Afobam), mogło działać na rzecz intensyfikacji procesów biomedykalizacji zaburzeń psychicznych. W modelowym ujęciu biomedykalizacyj-

1 Leki te są niezwykle popularne m.in. w USA: https://www.nejm.org/doi/full/10.1056/ NEJMp1715050 (dostęp: 16.06.2018 r.). 
nym wystarczy bowiem określona kombinacja leków, aby jednostka miała (dzięki lekom antydepresyjnym) pod kontrolą swoje długofalowe samopoczucie (Clarke et al. 2003: 182), mogła wyeliminować bieżące wahania nastroju czy okazjonalne manifestacje lęku (poprzez środki uspokajające dawkowane doraźnie), a nawet regulować procesy fizjologiczne, jak sen (czemu służyć mogą leki nasenne). W ten sposób dokonuje się, akcentowana w ramach biomedykalizacji, kontrola „biologicznych procesów" (w tym wypadku zachodzących wewnątrz organizmu) przez daną osobę (Clarke et al. 2003: 164).

Leki psychotropowe, zarówno środki antydepresyjne, jak i doraźnie działające medykamenty uspokajające, odgrywają, do tej pory, istotną rolę w leczeniu zaburzeń lękowych (Cujipers et al. 2013). W wielu badaniach klinicznych testujących skuteczność i przydatność danego medykamentu w terapii medycznej studiuje się i analizuje, w jaki sposób leki oddziałują na ludzi, jakie efekty generują. Ja natomiast zdecydowałem się przyjąć perspektywę odwrotną - postaram się ukazać, co ludzie mogą robić z przepisanymi im lekami psychotropowymi, określić, jakie praktyki mogą kształtować się wokół farmakoterapii (przynajmniej w przypadku osób cierpiących na zaburzenia lękowe). Innymi słowy, będzie mnie interesować kwestia sprawczości pacjentów w kontekście podejmowanej przez nich farmakoterapii, ich działania w odniesieniu do przyjmowanych leków.

\section{Antropologiczne badania nad lekami psychotropowymi}

W antropologicznych badaniach nad stosowaniem leków psychotropowych podejmowano między innymi kwestie na styku obywatelstwa, marginalizacji społecznej usuwanej lekami antydepresyjnymi oraz lokalnych koncepcji dobrostanu psychicznego w Indiach (Ecks 2005), czy obrotu leków psychotropowych na czarnym rynku - również w Indiach (Ecks, Basu 2014). Realizowane były też badania obejmujące strategie przemysłu marketingowego, związane $\mathrm{z}$ budowaniem obrazu leków psychotropowych oraz ustosunkowanie się pacjentów względem takich leków, a także strategii leczenia nimi osób mających dolegliwości psychiczne w Stanach Zjednoczonych (Martin 2006). Warto również wskazać badania realizowane w trybie etnograficznym przez socjologa Andre Lakoffa, który eksplorował relacje między lekarzami a przedstawicielami lokalnych firm farmaceutycznych w Argentynie w okresie kryzysu ekonomicznego (Lakoff 2004). Ze wskazanych prac najbliża pracy niniejszej jest, mimo bardzo wielu różnic, praca Emily Martin (2006) - jakkolwiek autorkę interesują praktyki marketingowe przemysłu farmaceutycznego oraz praktyki kombinacji leków psychotropowych w zaleceniach lekarskich, to jej uwagi nie zwraca natomiast w ogóle kwestia praktyk, jakie mogą dokonywać się na linii pacjent-medykament. Tymczasem to właśnie ten ostatni obszar można z perspektywy antropologa uznać za interesujący: pokazywać on może bowiem realny przebieg leczenia farmakologicznego. Temu właśnie obszarowi, który nie pojawia 
się także w innych przywołanych wyżej pracach, chcę poświęcić niniejszy tekst. Badanie legalnych i nielegalnych obiegów medykamentów psychotropowych (co robi się w przywołanych tekstach) to bowiem istotna kwestia, ale nie mniej istotną kwestią jest studiowanie „gospodarowania” lekami przez samych pacjentów.

\section{Koncepcje sprawczości}

Sprawczość pojawia się w antropologii w różnych, nieraz zaskakujących, kontekstach (zob. np. Kościańska 2009); jakkolwiek jej prymarne znaczenie obejmowało ludzkie działania we wzajemnym odniesieniu do struktury społecznej (Ahearn 2000: 12). Sprawczość bywa na przykład pojmowana w kategoriach „oporu i przeciwstawiania się" (czemuś) bądź w odniesieniu do praktyk, których bazą jest wolna wola lub świadomy wybór jednostki (Kockelman 2007: 375-376). Może być także definiowana jako „znaczna dowolność w wyborze i operowaniu środkami, by osiągać określone cele" (Kockelman 2007:375). W odniesieniu do kwestii związanych $\mathrm{z}$ chorobą i zdrowiem sprawczość może manifestować się jako dążenie do zdrowia poprzez korzystanie, przykładowo, wyłącznie z praktyk etnomedycznych lub z medycyny alternatywnej zamiast biomedycyny albo indywidualnym doborze praktyk i środków, oferowanych przez obszar biomedycyny (preferowanie jednych terapii ponad inne). W ramach sprawczości pacjent może na przykład poprosić lekarza o wypisanie danego konkretnego leku albo przeciwnie - odmówić przyjmowania leku wybranego przez lekarza, lub też - zreorganizować rozplanowaną przez medyka terapię lekami. Można sprawczość, na poziomie elementarnym, konceptualizować w aspekcie możliwości podmiotów ludzkich do wykreślania własnych „ścieżek" i odnajdywania przestrzeni autonomii w obrębie uwarunkowań kulturowo-społecznych, w jakich się znajdują (De Certeau 2008; Rakowski 2009; Ngai 2010). Pojmuję więc sprawczość jako kategorię, która:

podkreśla [...] niezdeterminowany charakter działania ludzkiego, przeciwstawiając się determinizmowi teorii strukturalnych. Niekiedy nadaje mu się [pojęciu sprawczości - K.G.] szersze znaczenie, aby zwrócić uwagę na psychologiczny i psychospołeczny aspekt aktora i uzasadnić jego zdolność do podejmowania działań zgodnie z własną wolą (Marshall 2005: 353).

\section{Pluralizm medyczny w leczeniu zaburzeń lękowych}

W najogólniejszym skrócie, pluralizm medyczny może być rozumiany jako „zjawisko nakładania się na siebie różnych systemów postępowania terapeutycznego" (Baer 2004: 109). Zjawisko to może się przejawiać na przykład w postaci przenikania się "tradycyjnych" metod leczniczych z bardziej nowoczesnymi, biomedycznymi formami terapii (Baer 2004; Penkala-Gawęcka 2010). Leczenie zaburzeń 
lękowych przebiega, co będzie istotne w dalszej części tekstu, właśnie pod auspicjami medycznego pluralizmu: $\mathrm{w}$ ramach często integrowanych $\mathrm{z}$ sobą dwóch, mimo wszystko odrębnych, domen postępowania terapeutycznego, nadzorowanych przez odmiennych specjalistów (Baer 2004: 109-110; Penkala-Gawęcka 2010): farmakoterapii oraz psychoterapii (zarówno jedna, jak i druga przewiduje odmienny paradygmat postępowania $\mathrm{w}$ przypadku leczenia jednostki z zaburzeniami lękowymi). Rzecz jasna, pacjent może zdecydować się na terapię u psychoterapeuty, rezygnując z możliwości kuracji lekami - albo też postąpić na odwrót. Możliwe jest przy tym korzystanie $\mathrm{z}$ lecznictwa prywatnego albo z państwowej służby zdrowia. Jeżeli dodamy do tego informację, że możliwe jest korzystanie $\mathrm{z}$ różnych szkół terapeutycznych (np. poznawczo-behawioralnej, gestalt, psychodynamicznej), z terapii grupowej lub indywidualnej oraz z różnych kategorii leków zarówno antydepresyjnych, jak i uspokajających czy działających nasennie, a także substancji ziołowego pochodzenia, to wówczas wyłania się obraz leczenia zaburzeń lękowych jako umiejscowionego w ramach styku różnych form, metod i środków terapeutyczno-leczniczych. Ktoś może, przykładowo, przyjmować lek antydepresyjny Escitil, medykament uspokajający Rispolept, doraźny lek benzodiazeopinowy Cloranxen, na dodatek jeszcze uczęszczać na psychoterapię grupową. W niniejszym tekście będę się jednak koncentrować głównie (chociaż niewyłącznie) na praktykach i opiniach związanych z lekami psychotropowymi.

\section{Kontekst lokalny: sytuacja ograniczonych danych}

W Polsce branża aptekarska odnotowuje wielomilionowe zyski ze sprzedaży samych tylko antydepresantów. Jak wskazują badania zorganizowane przez Instytut Zarządzania w Ochronie Zdrowia: „sprzedaż leków antydepresyjnych w Polsce rośnie lawinowo. W 2001 roku apteki wydały około 10 milionów opakowań. W 2008 roku 13 milionów. W 2013 roku już 19 milionów. W przybliżeniu Polacy wydają więc na antydepresanty 551 milionów zł rocznie”"2. W 2017 roku apteki sprzedały 21,1 miliona opakowań zawierających same tylko leki antydepresyjne ${ }^{3}$. Przywoływane dane sugerują, iż leki psychotropowe są w Polsce niezwykle często przepisywane przez lekarzy, a zatem, jak można sądzić, stanowią jeżeli nie podstawę, to z pewnością ważny element leczenia psychiatrycznego zaburzeń psychicznych. Można także domniemywać, że procesy medykalizacji dolegliwości psychicznych obserwowalne w krajach Zachodu w jakimś stopniu mogą dotykać również polskie społeczeństwo. Warto w tym miejscu zaznaczyć, że nie uda-

2 za: http://www.rynekaptek.pl/farmakologia/pol-miliarda-na-antydepresanty,7213.html (dostęp: 15.06.2015).

3 „Kiedyś Polacy wstydzili się przyznać do tej przypadłości. Dziś kupują rekordowe ilości leków mających ją zwalczyć", http://zdrowie.gazeta.pl/Zdrowie/7,101580,22937903,kiedys-polacywstydzili-sie-przyznac-do-tej-przypadlosci-dzis.html (dostęp: 17.06.2018 r.). 
ło mi się dotrzeć do badań antropologicznych, które poruszałyby wątek praktyk społecznych związanych z lekami psychotropowymi i leczeniem osób dorosłych w Polsce (ani społecznego dyskursu na temat takich leków). Jest to, być może, pokłosie sytuacji lokalnej: antropologia psychiatrii (czy też: antropologia zaburzeń psychicznych) stanowi stosunkowo słabo rozwinięte w Polsce pole badaw$\mathrm{cze}^{4}$; rodzimi antropolodzy medyczni dużo bardziej koncentrują się na chorobach związanych z „ciałem” niż na problematyce zaburzeń psychicznych. Z kolei w pracach naukowych autorstwa lekarzy medycyny dominuje studiowanie tego, w jaki sposób dany lek sprawdza się w leczeniu danego zaburzenia, nie zaś perspektywa nastawiona na wychwycenie praktyk, jakie z lekami mogą podejmować pacjenci ${ }^{5}$.

W kontekście dostępnych, a istotnych z punktu widzenia tego artykułu danych warto jeszcze poszukać odpowiedzi na pytanie, ile osób w Polsce zmaga się z zaburzeniami lękowymi. W badaniu ilościowym służącym określeniu ogólnej skali zaburzeń psychicznych w społeczeństwie polskim, realizowanym na terenie Polski od listopada 2010 do marca 2011 roku, co dziesiąta osoba ankietowana deklarowała doświadczanie takiej lub innej odmiany zaburzeń lękowych. Wyjąwszy uzależnienia od alkoholu i różnego rodzaju substancji narkotycznych, czyni to zaburzenia lękowe najsilniej rozpowszechnioną kategorią zaburzeń psychicznych w obrębie wyselekcjonowanej grupy respondentów ${ }^{6}$. Jeżeliby dokonać ekstrapolacji wyników przywoływanego badania, wówczas można powiedzieć, że nawet ok. 10 procent społeczeństwa polskiego może cierpieć na jakąś odmianę zaburzeń lękowych.

\section{0 rozmówcach i sposobach pozyskiwania danych}

Dane empiryczne pochodzą z wywiadów otwartych przeprowadzonych z 29 osobami, które zmagają się z zaburzeniami lękowymi. Wywiady zrealizowano w latach 2015-2017. Badania były przeprowadzone w Polsce, wśród polskich pacjentów. Zwracano uwagę, by rekrutowane do badań osoby miały postawioną (przez psychologa-psychoterapeutę bądź psychiatrę) diagnozę o występowaniu wzmiankowanych zaburzeń ${ }^{7}$ Niektóre osoby poinformowane zostały przez lekarzy, że

4 Jako osoby prowadzące badania z zakresu antropologii psychiatrii można wymienić Annę Witeskę-Młynarczyk i Andrzeja Perzanowskiego.

5 Jako przykład można przywołać pismo „Farmakoterapia w Psychiatrii i Neurologii”. Hasło „Zaburzenia lękowe” wywołuje z wyszukiwarki wspomnianego pisma sześć artykułów: każdy dotyczy tego, jak dany lek oddziałuje na pacjenta i na ile może być zastosowany w leczeniu zaburzeń lękowych.

6 http://www.ezop.edu.pl/05-Podsumowanie.pdf (dostęp: 15.06.2015 r.).

W W ramach zaburzeń lękowych wyróżnić można takie jednostki kliniczne, jak: fobia społeczna, agorafobia, fobie o charakterze specyficznym, generalne (uogólnione) zaburzenia lękowe, napady paniki, zaburzenia obsesyjno-kompulsyjne, niepokój codzienny, a także zespół stresu pourazowego (Seligman, Walker, Rosenham 2003). 
dotknęło je konkretne zaburzenie lękowe, na przykład fobia społeczna czy zespół stresu pourazowego; inne wiedziały tylko, że cierpią na zaburzenia lękowe (często takie osoby określały wskazane zaburzenia mianem „nerwicy”), nie wiedziały natomiast, jakie są to dokładnie zaburzenia lękowe9. Stąd też tylko w przypadku niektórych rozmówców będę informował, z jakim konkretnym zaburzeniem lękowym przyszło im się zmagać.

W skład grupy rozmówców wchodzi 21 kobiet i 8 mężczyzn, a dysproporcja taka po pierwsze wynika $z$ faktu, że, według stanowiska psychiatrów i psychologów klinicznych, to kobiety mają częściej zmagać się z zaburzeniami lękowymi; po drugie zaś jest ona funkcją tego, że w głównej przestrzeni, w jakiej pozyskiwałem potencjalnych rozmówców (grupy na serwisie społecznościowym Facebook, w których uwagami i opiniami wymieniają się osoby z różnego rodzaju zaburzeniami psychicznymi: depresją, zaburzeniami lękowymi, schizofrenią), częściej udzielają się kobiety. Przewaga kobiet wśród osób z zaburzeniami psychicznymi była różnie eksplikowana, przy czym niektóre wyjaśnienia (np. hipoteza o niezadowoleniu $\mathrm{z}$ roli gospodyni domowej wśród kobiet w USA jako potencjalnym źródle zaburzeń) były obalane przez bardziej szczegółowe badania empiryczne (Haggett 2009). Jak wskazuje Jonathan Metzl (2003), bazując jednak na danych dotyczących obywatelek USA, jeszcze w latach 60. i 70. dyskursy reklamujące i rekomendujące leki psychotropowe sprofilowane były na specyficzną kategorię odbiorców, którą tworzyć miały białe zamężne kobiety; w ten sposób wykrystalizowała się wizja leczenia wskazanymi medykamentami jako leczenia, którego odbiorcami są przede wszystkim kobiety (przypisanie danego leczenia do określonej kategorii społecznej). Genderowa dysproporcja w gronie moich rozmówców może być jednak motywowana zupełnie odmiennymi czynnikami; ich dokładne określenie wymagałoby jednak odrębnych badań, uwzględniających wywiady otwarte z psychiatrami oraz lekarzami innych specjalizacji, a także badanie rejestrów psychiatrycznych ${ }^{10}$.

Moi rozmówcy tworzyli grupę relatywnie zróżnicowaną socjologicznie: zarówno w kontekście wieku, jak i wykonywanego zawodu (np. bibliotekarze, osoby prowadzące własny biznes, informatycy, osoby studiujące czy bezrobotni). Przeważały jednak osoby zamieszkujące w środowisku miejskim: w miastach zarówno małych (Ostróda), średniej wielkości (jak np. Radom), jak i dużych (Warszawa, Łódź). Większa część rozmówców miała wykształcenie przynajmniej średnie, a spora grupa osób legitymowała się wykształceniem wyższym. Czworo osób miało za sobą pobyty na oddziałach psychiatrycznych. Większość w momencie

8 Określenie to było kiedyś stosowane w psychiatrii, jednak obecnie nie używa się go: termin „nerwica” zastąpiło określenie „zaburzenia lękowe”.

9 Tym bardziej że zaburzenia lękowe mają tendencję do współwystępowania.

10 Być może genderowa nierównowaga $\mathrm{w}$ grupie rozmówców motywowana była tak prozaicznym faktem, że to kobiety, nie zaś mężczyźni, odczuwały potrzebę udzielania się w wirtualnych grupach integrujących osoby z zaburzeniami psychicznymi. 
przeprowadzania wywiadu podejmowała albo psychoterapię, albo terapię farmakologiczną, a czasem łączyła obie te formy leczenia. Okres przyjmowania leków kształtował się bardzo różnie: były osoby, które przyjmowały dane leki od miesięcy lub tygodni, a nawet kilku dni od momentu przeprowadzenia z nimi wywiadu. Trudno jednak wskazać na jednoznaczne korelacje między czasem przyjmowania leku a opisywanymi praktykami: na przykład praktykę manipulacji dawkami podejmowała zarówno Joanna [21] przyjmująca lek od nieco ponad tygodnia do momentu przeprowadzenia wywiadu, jak też Natalia [50] biorąca medykamenty przez wiele lat.

Do materiałów, mających postać wywiadów otwartych dołączam również konwersacje, jakie przeprowadziłem poprzez serwis społecznościowy Facebook z dwiema kobietami, również cierpiącymi na zaburzenia lękowe (obie wiedziały, że dane posłużą mi w celach naukowych). Pewna część moich badań była realizowana $\mathrm{w}$ środowisku wirtualnym, w sferze online. Miało więc miejsce coś, co Robert Kozinets określa mianem „etnografii mieszanej” (Kozinets 2012: 103): integrującej metody etnografii tradycyjnej (w tym wypadku: wywiady z pacjentami) oraz netnografii, przebiegającej już w przestrzeni internetu (pozyskiwanie rozmówców poprzez internet, wykorzystywanie materiałów publikowanych na portalach społecznościowych, a także, w dwóch przypadkach, wywiady poprzez czat portalu społecznościowego Facebook) (por. Cichocki 2012: 24 i n.; ChowaniecRylke 2018). Obecnie pacjenci cierpiący na różne choroby i zaburzenia mogą dość swobodnie i bez żadnych formalnych barier łączyć się w wirtualne zbiorowości, te zaś pełnią istotne funkcje: między innymi poradnicze (Chowaniec-Rylke 2018) czy psychologiczne (są nastawione na wspieranie swoich członków). Na Facebooku można znaleźć wiele grup, w których skupiają się pacjenci zmagający się z różnymi chorobami i zaburzeniami. Rekrutowanie rozmówców w tego rodzaju grupach jest więc reagowaniem na wzorce zachowań współczesnego pacjenta (zob. Schilling 2008), co w tym wypadku wymusza kierowanie się przez antropologa do przestrzeni, na jaką te osoby się orientują ${ }^{11}$.

Dwa z przeprowadzonych przez sieć wywiadów można wpisać w nurt „wywiadów netnograficznych" (Kozinets 2012: 159): metody czerpania danych dzięki bezpośredniemu uczestnictwu w określonych społecznościach sieciowych i komunikacji z ich członkami. W tym wypadku dane zbierane drogą takich wywiadów mają znaczenie uzupełniające: służyły mi do uściślenia, uszczegółowienia pewnych kwestii, nie stanowiły zaś zasadniczej metody gromadzenia danych analitycznych (ta rola przynależy do wywiadów „tradycyjnych”). Jakkolwiek wywiady te trwały krócej, zadawałem w ich trakcie analogiczne pytania jak w wywiadach „tradycyjnych”. Odnośnie do odwoływania się do publikowanych w dwóch wska-

11 Jakkolwiek nie implementuję w tym tekście perspektywy ANT (teorii aktora-sieci) - kładę bowiem nacisk na sprawczość podmiotów ludzkich, nie zaś nie-ludzkich - jednak, w szerokim sensie, skierowanie uwagi na sieć może być interpretowane jako realizacja ANT-owskiego postulatu „podążania za aktorami” (zob. Abriszewski 2007). 
zanych grupach ${ }^{12}$ materiałów, to czynię to, $\mathrm{w}$ dwóch przypadkach przywołując motywy internetowego dyskursu pacjenckiego na temat leczenia zaburzeń psychicznych - celem poszerzenia kontekstu realizowanych badań (zebrane na użytek niniejszego artykułu opinie można bowiem rozważać jako umieszczone $\mathrm{w}$ pewnym szerszym dyskursie). W wymiarze metodologicznym jest to bazowanie na „danych archiwalnych": zastanych danych funkcjonujących w sieci i wytwarzanych przez zaangażowane w komunikację wirtualną osoby (Kozinets 2012: 143). Celowo przywołuję te dane za pomocą formuły parafrazowania - istotne jest bowiem dla mnie nie tyle bazowanie na dokładnych cytatach i językoznawcza analiza tychże, ile ogólne określenie wyrażanego stanowiska pacjentów (dodatkowo w ten sposób chronię anonimowość autorów tych opinii, publikujących w interesujących mnie grupach pod imieniem i nazwiskiem).

Spora część z osób spośród tych, które zdecydowały się udzielić mi wywiadu, przyjmowała leki psychotropowe i ich praktyki będą dla mnie istotne; pewna grupa zdecydowała się nie przyjmować leków, ale niektóre formułowane przez nich opinie na temat farmakoterapii również mogą posłużyć jako użyteczny materiał badawczy. Zaznaczam, że zgodnie z dobrą praktyką antropologiczną ukryłem prawdziwe imiona moich rozmówców, zastępując je fikcyjnymi. Przywołując cytat lub imię któregoś z rozmówców, w nawiasie kwadratowym przywołuje także wiek danej osoby.

\section{Próba rozstrzygnięcia wątpliwości metodologicznych}

Zasadne jest poruszenie kwestii tego, na ile moje badanie jest, $\mathrm{z}$ uwagi na specyfikę materiału badawczego, badaniem praktyk społecznych, nie zaś wyłącznie dyskursu czy narracji pacjenckich (skądinąd badanie dyskursu czy narracji jest relatywnie popularne $\mathrm{w}$ antropologii medycznej). $\mathrm{W}$ pewnym sensie zajmuję się tutaj badaniem dyskursu ${ }^{13}$ pacjentów - przybliżam w końcu ich opinie na temat leków psychotropowych. Ale też staram się wyjść poza ten dyskurs, przedstawić charakterystykę praktyk podejmowanych z lekami. Jeżeli dany pacjent mówi, że na przykład zamiast $50 \mathrm{mg}$ leku zaleconego przez lekarza konsumuje $25 \mathrm{mg}$, to można to analizować $\mathrm{w}$ trybie analizy dyskursu, ale można również w tym widzieć zdawanie relacji z praktyki, jaka ma miejsce w przypadku danego leku i podejmowana jest przez daną osobę; relacji, której nie da się zredukować wyłącznie do motywu dyskursywnego. Informacje o tych praktykach czerpię co prawda z wywiadów otwartych, nie zaś z obserwacji uczestniczącej, jednak ma to istotne uzasadnienie. Wskazywano, że obszar biomedycyny jest relatywnie trudny do

12 Celowo nie podaje nazw pozwalających zidentyfikować wskazane grupy.

13 Kategorię dyskursu rozumiem tutaj następująco: dyskurs to wspólnota przekonań, poglądów, wartości, ideologii dominujących w określonej zbiorowości, w tym wypadku zbiorowości pacjentów. Zbiorowość ta tworzy „wspólnotę dyskursu” (Swales 1990, za: Wodak 2011: 30). 
eksploracji etnograficznej i wymusza często na antropologu rezygnację z metody obserwacji uczestniczącej i poprzestanie na stosowaniu metody wywiadu (otwartego, etnograficznego) (Wierciński 2010a). W mojej sytuacji bazowanie na danych pochodzących $\mathrm{z}$ wywiadów otwartych motywowane jest tym, że grupę rozmówców stanowią ludzie chorujący na zaburzenia psychiczne - jakkolwiek nieprzebywający w szpitalach, to jednak tacy, których codzienność jest, w jakiejś części, zdefiniowana zmaganiami z zaburzeniami lękowymi. Zasadne jest wobec tego domniemanie, iż badania w trybie obserwacji uczestniczącej, na przykład w domach rozmówców, niekoniecznie byłyby wskazane: stała obecność antropologa w przestrzeni domowej mogłaby stanowić dodatkowy czynnik stresogenny, odbijać się negatywnie na samopoczuciu pacjenta (a zatem utrudniać proces zdrowienia). Nadto obecność antropologa ingerowałaby w życie nie tylko rozmówców, ale także i ich krewnych czy partnerów, z jakimi zamieszkiwało wielu moich rozmówców. Stąd też dane pozyskiwane są na użytek niniejszego artykułu metodą, by tak to ująć, pośrednią, a wybór takiej metody motywowany był wolą przestrzegania zasady „po pierwsze nie szkodzić" jako kluczowej, która obowiązuje nie tylko lekarza, ale również antropologa - zwłaszcza w przypadku badań z osobami przewlekle chorymi. Stąd też takie, a nie inne źródło danych stanowi wynik kompromisu etyki i metodyki. Relacje o praktykach czy też znaczenia dyskursywne mogą zaś zawierać się zarówno w większych, kilkuzdaniowych strukturach językowych, jak i w krótkich, pojedynczych zdaniach (por. Czyżewski 2008); stąd też przywoływać będę zarówno jedne i drugie, nie dokonując rozróżnień, które z nich mają bardziej „wartościowy” charakter.

\section{Czy leki leczą? Opinie na temat leków psychotropowych}

Poniżej chciałbym przybliżyć postawy moich rozmówców względem leków psychotropowych, takich jak środki antydepresyjne oraz doraźnie działające leki uspokajające. Takie medykamenty były im bowiem przepisywane przez lekarzy. Ta część pracy jest konceptualnie zbliżona do powstających w ramach antropologii medycznej studiów, w których analizuje się postawy pacjentów względem określonych terapii (Wierciński 2010a) czy nawet technologii medycznych (Wierciński 2010b).

W skrócie można powiedzieć, że moi rozmówcy z zaburzeniami lękowymi artykułowali pogląd, że leki psychotropowe, jakkolwiek trudno im odmówić pozytywnego oddziaływania, nie są de facto $\mathrm{w}$ stanie wyleczyć zaburzeń lękowych. Był to wątek obecny zarówno w wypowiedziach osób, które przyjmowały medykamenty, jak i u tych, które nie zdecydowały się na taki krok. Oto co konstatowała Karolina [23], przyjmująca środek antydepresyjny Asentra: „to nie jest tak, że leki mnie uzdrowią, uzdrowi mnie własna praca nad sobą". Zauważyć należy, że kwestia usunięcia zaburzenia jest tutaj definiowana odmiennie niż w kulturowych dyskur- 
sach medykalizujących zaburzenia psychiczne: nie lek, ale pacjent ma doprowadzać do usunięcia zaburzenia ${ }^{14}$; to, co jest w tej wypowiedzi akcentowane, to niewiara, że lek może „naprawić” psychikę rozmówczyni. Mamy więc do czynienia z odrzuceniem biomedycznej wizji leczenia zaburzeń lękowych jako opartej na naprawie rozregulowanych przez leki mechanizmów wewnętrznych (zob. Cohen 1993). Można w tym miejscu również przywołać opinię Martyny [29], która nie zdecydowała się na podjęcie farmakoterapii, tłumacząc to w sposób następujący: "problemy [...] tak czy siak nieprzepracowane wrócą, jak się te leki odstawi”. Idąc tokiem jej rozumowania, można stwierdzić, że środki psychotropowe skazywać mogą albo na nawrót przypadłości po odstawieniu leczenia, albo na ciągłe przyjmowanie danego środka. Mimo przyjmowania leku człowiek nie jest więc formalnie wyleczony. Jak ujmowała to inna osoba, korzystająca zarówno z farma-, jak i psychoterapii: „leki pomagają właśnie [się - K.G.] wyciszyć, natomiast terapia jest mi potrzebna po to, żebym odstawiła te leki i radziła sobie bez leków, żeby jakby w ogóle obejść się, wyleczyć się" [Sabina 43]. To odbycie psychoterapii jest według rozmówczyni kluczowe dla pozbycia się zaburzeń lękowych: „wyleczenie” sugeruje definitywne usunięcie zaburzeń i przeciwstawić je można „wyciszeniu”, jako odczuciu powstającemu po zażyciu leków psychotropowych - odczuciu, które można kojarzyć ze zmianami w samopoczuciu, jednak, jak się wydaje, niekoniecznie implikującymi, z perspektywy pacjentki, proces zdrowienia. Jest to różnica między odczuwalną ulgą (po lekach) a zupełnym wyzdrowieniem (po psychoterapii). Zauważyć należy, że psychoterapia jest konceptualizowana w powyższej wypowiedzi jako coś, co uwalnia także od konieczności przyjmowania leków psychotropowych: jej odbycie jest więc także w tym aspekcie korzystne dla podmiotu. Z kolei według innej osoby, oparcie się w leczeniu zaburzeń lękowych wyłącznie na farmakoterapii nie pozwala, jak to zostało ujęte, „uwolnić się” od konieczności stałego przyjmowania danego leku: „musiałbyś brać całe życie” [Paulina 34]. Tym samym kuracja stałaby się, by tak to ująć, „terapią permanentną", leczeniem pozbawionym końca. Artur Frank wprowadził do antropologii medycznej i socjologii medycyny pojęcie „społeczeństwa remisji" (remission society) jako określenie zbiorowości pacjentów formalnie wyleczonych z choroby nowotworowej, nad którymi wisi jednak fatum nawrotu choroby (Frank 2005). W odniesieniu do konsumpcji leków psychotropowych wskazać należy, że na grupach na Facebooku, w jakich starałem się pozyskiwać rozmówców, co jakiś czas przewijał się komentarz (publikowany przez różne osoby) sugerujący, iż leki tak naprawdę nie leczą zaburzeń psychicznych, a jedynie usuwają ich objawy - na czas brania danego medykamentu, de fac-

14 Wpisuje się to jednak w szerszy wymiar biomedykalizacji, akcentującej, że zdrowie jest czymś, za co prymarnie odpowiada jednostka (Clarke et al. 2003: 172-173, 181), jednak tutaj w ramach tej odpowiedzialności nie sięga się po to, co oferuje biomedycyna. W odniesieniu do wcześniej akcentowanej sprawczości można powiedzieć, że cytowana osoba wybiera inną drogę do osiągnięcia zdrowia psychicznego, niż poprzez kurację farmakologiczną (por. Metzl 2003: 122). 
to nie eliminując choroby. $\mathrm{W}$ kontekście takich opinii poleganie wyłącznie na farmakoterapii w leczeniu zaburzeń lękowych mogłoby oznaczać przynależność do grupy jednostek leczonych, lecz finalnie niewyleczonych (niewyleczalnych), nieodczuwających co prawda objawów zaburzenia, lecz nominalnie ciągle chorych.

\section{Lęk przed uzależnieniem}

Niechęć do długotrwałego przyjmowania leków korespondowała z tym, że moi rozmówcy bali się uzależnienia od środków psychotropowych. Perspektywa ewentualnego uzależnienia powodowała zresztą, że niektórzy $\mathrm{z}$ nich $\mathrm{w}$ ogóle nie decydowali się na kurację jakimikolwiek lekami antydepresyjnymi czy benzodiazepinowymi. W ramach egzemplifikacji można tutaj przywołać przypadek Agnieszki [24], cierpiącej między innymi na fobie specyficzne (gwałtowny strach przed wojną, przed końcem świata, lęk przed kontaktami z ludźmi będącymi pod wpływem alkoholu) oraz zaburzenia obsesyjno-kompulsywne (natrętne myśli o tym, że mogłaby zabić swoją matkę albo inne osoby). Podejmowała ona leczenie u psychoterapeuty, jednak nie zdecydowała się na przyjmowanie leków psychotropowych właśnie z uwagi na to, że mogłaby po nich wpaść w stan uzależnienia - co miało wcześniej spotkać jej ojca:

Znaczy no ja... ogólnie mój tata bierze jakiś tam lek uspokajający od lat. Cały czas ten sam, więc na pewno jest od niego mocno uzależniony, już jestem nawet pewna tego... i wiem, że jak go nie weźmie, wiem, jak on się zachowuje, wiem, że jest rozdrażniony, jest dużo gorzej, ma jakieś te swoje... boi się wiatru dajmy na to, jakieś takie pierdoły [Agnieszka, 24].

W tym przypadku uzależniające działanie leków jest obserwowane na przykładzie członka bliskiej rodziny; rozmówczyni uzyskuje więc, po pierwsze, empiryczny dowód na możliwość popadnięcia w uzależnienie pod wpływem leków psychotropowych, jak też, po drugie, ogląd z pierwszej ręki sytuacji pacjenta, który w takie uzależnienie popadł (zaobserwowane zostało pojawienie się fobii u ojca Agnieszki). Kształtuje to „antylekowe” nastawienie u mojej rozmówczyni ${ }^{15}$.

15 Na zasadzie dygresji można dodać, że czasami, gdy opisywano konsumpcję medykamentów psychotropowych, stosowano leksemy czy zwroty, jakie zwykle pojawiają się w kontekście zażywania narkotyków. Wspominano np. o stanie „naćpania” odczuwanym po zażyciu danego leku [Wiktoria, 23]. Żaneta [31] tak relacjonowała odstawienie leków w związku z kolejną planowaną ciążą: „nie, już teraz od dwóch tygodni nie biorę, więc... czysta jestem, jakimś kurde narkomanem [jestem - K.G.], jakimś... [śmiech]”. 


\section{Psychoterapia a farmakoterapia w opiniach rozmówców}

Warto również określić, jak moi rozmówcy postrzegali farmakoterapię w porównaniu do psychoterapii. Otóż wielu rozmówców deklarowało swoją wiarę w skuteczność psychoterapii, jednak nie deklarowało jej aż w takim stopniu względem leków psychotropowych. Czasami w analizowanych wywiadach rozpatrywano stosunek między psychoterapią oraz leczeniem farmakologicznym, jednak zwykle w takich zestawieniach wyraźnie zaznaczało się, jaka forma leczenia uważana była za istotniejszą. Marek [27], który przyjmował lek antydepresyjny i odbywał terapię u psychologa, zapytany przeze mnie (rozmawialiśmy o możliwych sposobach leczenia zaburzeń lękowych), co by się stało, gdyby hipotetyczny pacjent postanowił udać się na psychoterapię bez podejmowania farmakoterapii, odparł, że taką drogą można by pozbyć się zaburzeń lękowych, jednak odwrotna sytuacja - podjęcie farmakoterapii, a zaniechanie wizyt u psychologa - przyniosłaby o wiele gorsze skutki: „psychiatria bez psychologii moim zdaniem się nie uda, uda się na czas brania farmakologii plus do roku”. Joanna [21], cierpiąca na fobię społeczną, była chyba najbardziej spośród moich rozmówców przychylna farmakoterapii (oddając to w sposób ekstatycznie żartobliwy: „chwała Big Pharmie, że to wynalazła, chwała wielkiej farmacji”). Podczas wywiadu, odbywającego się krótko po rozpoczęciu leczenia antydepresantami, wskazywała, jak bardzo poprawiło jej się samopoczucie po zażywanych lekach (wyeliminowany został silny lęk towarzyszący jej w pracy), jednak zasugerowała również, iż zamierza podjąć regularne wizyty u psychologa: „ktoś to musi w końcu rozplątać, ja tego kurwa nie rozplączę, przykro mi bardzo”. A zatem to właśnie psychoterapia będzie w opinii pacjentki kluczowa dla wyleczenia się z zaburzeń lękowych - tam bowiem będzie miało miejsce owo „rozplątanie” jej psychiki: ma to zrobić psycholog. W tym przypadku nawet ewidentna poprawa samopoczucia po zażywaniu leków nie sprawia, że dana osoba czuje się zdrowa - raczej czuje się, by tak to ująć, mniej chora: nie odczuwa skutków swojego zaburzenia w obszarze pracy zawodowej, a więc jednej tylko, jakkolwiek istotnej, przestrzeni egzystencji. W narracji Marty [40] pojawił się wątek leków psychotropowych, które winny być zażywane między innymi z uwagi na to, że poprawiając samopoczucie, pozwalają właśnie na uczestnictwo w psychoterapii: „uważam, że jak ktoś nie daje rady normalnie funkcjonować, to powinien się poratować [lekami - K.G.], bo terapia to jedno, ale na nią też trzeba mieć siłę". Jedno leczenie specjalistyczne może wspierać tym samym inne i przez to działać na korzyść pacjenta. Według tej opinii, farmakoterapia przyczyniać się może do zaistnienia efektu leczącego w ten sposób, że umożliwia pacjentowi podjęcie psychoterapii: działa sama, ale przede wszystkim - pozwala oddziaływać psychoterapii na pacjenta. W innym przypadku wybór leków, a nie psychoterapii, był wyborem stricte ekonomicznym. Taka sytuacja miała miejsce u Natalii [50], która przez pewien czas po rozstaniu z mężem miała problemy ekonomiczne (była samotną matką) i nie stać jej było na wizyty u psychologa, 
a nie chciała uczęszczać na terapię w ramach NFZ, więc zażywała spore dawki leków psychotropowych. Gdy jednak poprawiła się jej sytuacja finansowa, zdecydowała się na podjęcie prywatnej psychoterapii, dzięki której, jak twierdzi, pozbyła się zaburzeń lękowych. W tej sytuacji leczenie środkami antydepresyjnymi i uspokajającymi zastępuje niejako leczenie preferowane przez pacjentkę, które nie jest (chwilowo) dla niej dostępne; farmakoterapia jest świadomie traktowana przez rozmówczynię jako terapia o charakterze substytutywnym i przejściowym, realizowana w odniesieniu do materialnej kondycji rozmówczyni, nie zaś do jej faktycznej potrzeby.

A zatem dla zdecydowanej większości moich rozmówców wyleczenie możliwe jest $\mathrm{w}$ ramach psychoterapii. Stosunek między dwiema omawianymi wyżej formami terapii można w takim wypadku ująć jako relację bazy i nadbudowy, gdzie tę pierwszą, stanowiącą zasadniczy rdzeń postępowania terapeutycznego, stanowi psychoterapia, tę drugą zaś - raczej wspomagającą leczenie zasadnicze niż samoistnie usuwającą problemy ze zdrowiem psychicznym - leczenie farmakologiczne. Moi rozmówcy często opowiadali się natomiast przeciwko leczeniu środkami psychotropowymi jako wyłącznej formie terapii. Płynie z tego wniosek, że pacjenci z zaburzeniami lękowymi, z którymi przeprowadzałem wywiady, mieli własną wizję porządku leczenia tych zaburzeń.

\section{Co można robić z lekami? Praktyki rozmówców}

Wyróżniłem trzy praktyki związane z lekami, jakie podejmowane były przez moich rozmówców. Przedstawię je w poniższych podrozdziałach, w jednym momencie „przecinając” wywód nawiązaniem do przyjmowania przez rozmówców środków pochodzenia ziołowego (w ramach leczenia zaburzeń lękowych).

\section{Praktyka pierwsza: dawki i częstotliwość}

Znaczna część moich rozmówców otrzymywała recepty na leki psychotropowe: preparaty antydepresyjne lub działające doraźnie środki uspokajające. Bywało, że po decyzji lekarza prowadzącego następowały zmiany odnośnie do przepisanych leków - na przykład gdy nie odczuwano poprawy po określonym czasie dawkowania. Wśród moich interlokutorów były też jednak osoby, które decydowały się na samodzielną modyfikację ustalonych przez lekarza zasad przyjmowania leków. Przykładowo Dominika [22], która przez półtorej miesiąca przyjmowała Afobam (skądinąd oceniany przez nią jako lek skuteczny, uśmierzający jej lęki), nie poszła za wskazówkami lekarskimi, by spożywać jedną tabletkę dziennie przez okres miesiąca: 
poczytałam właśnie w grupie [facebookowej - K.G.], że po prostu branie codziennie uzależnia, i myślę, że nie ma potrzeby, żebym brała go codziennie, także biorę go doraźnie, jeżeli już czuję, że naprawdę muszę go wziąć, jak miałabym jakieś silne lęki, to wtedy właśnie go biorę i dwie godziny i po prostu mi pomaga [Dominika, 22].

Branie wspomnianego leku według zaleceń lekarza mogłoby odbić się ujemnie na zdrowiu Dominiki - natomiast przyjmowanie Afobamu według samodzielnie określonego wzorca oceniane jest jako zdecydowanie bezpieczniejsze rozwiązanie. Portal społecznościowy poszerza w tej sytuacji perspektywę interakcji rozmówczyni z lekiem o zagadnienie ewentualnego uzależnienia, co finalnie prowadzi do odrzucenia zaleceń lekarskich. Dominika jest za to przyzwyczajona do przyjmowania innego leku uspokajającego, Hydroksyzyny, w dawkach dużo większych od zalecanych przez lekarza. Inna moja rozmówczyni, wspomniana wcześniej Joanna [21], otrzymała receptę na lek Parogen. Bardzo chwaliła sobie oddziaływanie tego leku, jednak przez pewien czas nie decydowała się na zwiększenie zażywanej codziennie dawki, co po pewnym czasie zaleciła jej psychiatra - powodem była obawa Joanny, że może znaleźć się w sytuacji, gdy nie będzie mogła wziąć tabletki, gdy kuracja nie będzie mogła być kontynuowana: „jakoś mało tego zostało, przeliczyłam sobie, kiedy dostanę następną receptę, i stwierdziłam, że to mało". Kontynuacja kuracji wymaga więc jej przemodelowania, odstąpienia od zaleceń lekarskich. Pacjentka postawiona jest przed wyborem: albo będzie musiała, nie z własnej woli, zawiesić kurację, albo ją kontynuować, ale z dokonaniem zmian. Z kolei Natalia [50] przyjmowała przez pewien okres lek antydepresyjny: sama sobie, stopniowo, zmniejszała dawkę tego leku, by go w końcu odstawić; analogicznie zmniejszała sobie dawki konsumowanego Afobamu, samodzielnie „schodząc z leku”. W tym wypadku kuracja farmakologiczna jest w znacznej części ustalana i planowana przez pacjentkę. Nieco inaczej postępowała natomiast Joanna [43], która z obawy przez skutkami ubocznymi przyjmowała w momentach lęku jedynie połowę z zalecanej dawki Zomirenu (połowę tabletki zamiast całej - jak sugerowała to jej psychiatra). Jednak w trakcie podróży samolotem przyjęła w ciągu godziny aż trzy tabletki: z powodu stresu wywołanego lotem. Gdy pytałem ją, jak to możliwe w sytuacji, w której bała się przyjmować dawkę rekomendowaną przez lekarkę, odpowiedziała: „uwierz mi, wtedy było mi wszystko jedno... po prostu strach przed lataniem był tak ogromny, że było mi wszystko jedno, tak?”. Ten ostatni przykład pokazuje, że dynamika zapotrzebowania i konsumpcji danego leku może być trudna do określenia i przewidzenia nawet dla samego pacjenta-biorcy środka psychotropowego ${ }^{16}$.

$\mathrm{W}$ trzech powyższych przypadkach ujawnia się jeden $\mathrm{z}$ istotnych wymiarów pacjenckiej sprawczości: możliwość wpływania na wielkość przyjmowanych dawek oraz częstotliwość ich konsumpcji. Manipulacja dawkami następuje nawet

16 Inspirowałem się w powyższej interpretacji rozważaniami Poppera dotyczącymi tego, jak trudno w naukach społecznych o prognozowanie i jak rzeczywistość społeczna obfitować może w zaskakujące sytuacje (Popper 1999). 
w sytuacjach, gdy rozmówcy pozytywnie oceniali działanie danego środka: nie jest to wyłącznie wyraz kontestowania farmakoterapii. Praktykę tę chciałbym określić jako „swobodne dawkowanie”.

\section{Praktyka druga: selektywna farmakologizacja}

Modyfikacje, o których mi wspominano, dotyczyły także tego, jakie leki decydowano się przyjmować. Ilustratywna w tym względzie jest historia Piotra [21], który przyjmując lek antydepresyjny Escitalopram oraz działającą uspokajająco Hydroksyzynę, nie zdecydował się na konsumowanie jeszcze jednego sugerowanego przez psychiatrę leku, Propranololu, jakkolwiek preparat ten został przez niego wykupiony. Wzmiankowany środek przepisała mu psychiatra, jednak druga, z którą się konsultował, przestrzegała go przed Propranololem, wskazując na liczne skutki uboczne, jakie ten wywołuje. Owa rozbieżność opinii (można by rzec: pole psychiatryczne ${ }^{17}$ skutecznie podminowuje samo siebie) skłoniła go do wstrzymania się z zażywaniem danego leku. Karolina [23] otrzymała receptę na dwa leki psychotropowe, jednak zdecydowała się na przyjmowanie wyłącznie jednego: medykamentu antydepresyjnego Parogen, rezygnując z przyjmowania wykupionego środka uspokajającego (Afobamu). Z kolei Ewelina [39] zaprzestała kuracji lekiem antydepresyjnym po tym, jak w wyniku kuracji przybrała osiem kilogramów na wadze, jednak zdarzało jej się okazjonalnie, w momentach szczególnie silnego napięcia i stresu, zażyć tabletkę Afobamu, który również otrzymała od psychiatry. Jak sama opowiada:

brałam cztery razy przez ostatni miesiąc. No na przykład w czasie burzy się nam coś z dachem zrobiło, zalało mi kuchnię, jak była kolejny raz jakaś duża ulewa, to ja nie spałam całą noc, serce mi waliło, no i Afobam sobie wzięłam [Ewelina, 39].

W tym przypadku kuracja lekami występuje w formie bardzo ograniczonej; nastąpiło okrojenie leczenia farmakologicznego. Kwestia wyglądu wypiera u rozmówczyni kwestię samopoczucia, prowadząc do zmodyfikowania kuracji. Zaznaczyć należy, że moi interlokutorzy częściej jednak decydowali się na przyjmowanie samego tylko leku antydepresyjnego - rezygnując z konsumpcji wypisanego lub zasugerowanego im środka o działaniu uspokajającym. Jakiekolwiek motywacje wchodziłyby tutaj w grę, opisywane działania można, jak sądzę, określić mianem „selektywnej farmakologizacji”: kiedy pacjent lub pacjentka decydują się przyjmować tylko wybrane przez siebie medykamenty z zestawu zaordynowanego im przez psychiatrów. Inaczej rzecz ujmując: leki przepisywane i wykupywane nie są lekami konsumowanymi (De Certeau 2008). Sprawczość jest tutaj związana

\footnotetext{
17 Na temat pola psychiatrycznego: Nowakowski 2013.
} 
z samodzielnym wyborem określonych środków leczniczych: preferowaniem jednych, rezygnacją zaś z zażywania drugich.

\section{Intermezzo: leki ziołowe stosowane przez rozmówców}

Kilkoro interlokutorów deklarowało również przyjmowanie środków ziołowego pochodzenia - takich jak: Validol, Revalid, Melissa, Nervosol. Opis interakcji rozmówców z tymi środkami jest istotny o tyle, że poszerza kontekst, $\mathrm{w}$ jakim zachodziło przyjmowanie leków psychotropowych przez osoby z zaburzeniami lękowymi.

Przykładowo Agnieszka [24], przyznawała, że zdarzało jej się sięgać po Melissę: „Melissę piję, o, dlatego, że lubię jako zioło, tak?”. Wzmiankowany środek jest w tym wypadku traktowany jako coś, co sytuuje się bardziej w kategorii „pożywienie” niż w kategorii „substancja lecznicza” - spożywany jest ze względu na właściwości smakowe (a być może również ze względu na pewną dozę przyzwyczajenia). Czasami wskazywano, że jeżeli chodzi o skuteczność oddziaływania, środki ziołowe nie mogą się równać z lekami. Justyna [26] opowiadała, że próbowała włączyć do kuracji Validol, jednak nie spełnił on jej oczekiwań: „po jakimś czasie, kiedy objawy się nasiliły, już nie dawał rady”. Środek ten początkowo znalazł się więc w kategorii „substancja lecznicza”, jednak po pewnym czasie z niej wypadł. Z kolei Marlena [25] należy do osób, które mają dobrą opinię o środkach ziołowych. Według jej opisów ziołowe substancje „wyciszają” oraz „zmniejszają objawy ataku”. Jednak w momencie, gdy przeprowadzałem $\mathrm{z}$ nią wywiad, nie przyjmowała takich środków, zamiast tego sięgała po uspokajające medykamenty benzodiazepinowe, przepisane i zasugerowane jej przez lekarza. Wskazywała jednak, że te ostatnie nie działają tak dobrze jak środki ziołowe. W tym wypadku terapia medyczna odsuwa to, co z perspektywy pacjentki było skuteczne: kuracja etnomedyczna zastąpiona jest biomedyczną, co jednak odbija się negatywnie na samopoczuciu pacjentki. Pozytywną opinię tej ostatniej osoby o środkach ziołowych można, jak sądzę, potraktować jako (synekdochiczną) egzemplifikację dyskursu, jaki funkcjonował w grupach na Facebooku, w których poszukiwałem rozmówców: dyskurs ten (nazwijmy go „etnomedycznym”) podkreślał znaczną efektywność (przewyższającą nawet działanie leków psychotropowych) środków ziołowych i suplementów, takich jak witaminy, w leczeniu zaburzeń psychicznych (nie tylko zaburzeń lękowych). W ramach tego dyskursu akcentowano, że substancje ziołowe i suplementy witaminowe są wystarczające w procesie leczenia zaburzeń psychicznych ${ }^{18}$.

Można suponować, że ze środkami o charakterze ziołowym nie wiążą się skutki uboczne porównywalne do tych wywoływanych przez leki przepisywane na

18 Kwestia specyfiki tego dyskursu i związanych z nim praktyk wymaga jednak szerszych, kie-

runkowych badań. Tu chodziło tylko o zasygnalizowanie problemu. 
receptę - dlatego, być może, niektórzy moi interlokutorzy zdecydowali się po nie sięgać; uwzględnić należy również fakt, że dostęp do tych środków jest relatywnie swobodny (kupuje się je bez recepty). W przypadku osób z zaburzeniami lękowymi dochodzi jednak jeszcze inny powód. Otóż substancje ziołowego pochodzenia były często sugerowane moim rozmówcom przez lekarzy rodzinnych lub farmaceutów: a zatem pojawiały się legitymizowane autorytetem reprezentantów obszaru biomedycyny. Tak było na przykład w przypadku Maksa [18], któremu lekarka rodzinna zasugerowała środek ziołowy Validol.

Zdarzały się również osoby, które w dość specyficzny sposób stosowały zarówno leki psychotropowe, jak i środki ziołowe. Dwa przykłady będą tutaj znaczące i wymagają omówienia.

Jedna z rozmówczyń, Sabina [43], jest osobą która zmaga się z zespołem stresu pourazowego (PTSD) po tym, jak w dzieciństwie była molestowana, potem zaznała przemocy domowej w małżeństwie, a na dodatek doświadcza sporego stresu w pracy zawodowej. Sabina uczęszcza na psychoterapię, leczy się farmakologicznie, dodatkowo stara się poprawiać sobie samopoczucie na przykład słuchaniem muzyki relaksującej czy regularnymi spotkaniami (według niej oddziałującymi korzystnie na psychikę) z innymi ludźmi. Można powiedzieć, że w jej praktykach manifestuje się pluralizm medyczny na poziomie mikro, pojmowany jako świadome łączenie programowo odrębnych metod (Penkala-Gawęcka 2010), aby wspomóc proces leczenia. Zaznaczyć również trzeba, że moja rozmówczyni integrowała różne środki, celowo łącząc lek psychotropowy oraz substancję ziołową, dawkując je obydwa w ramach cowieczornego rytuału po to, by osiągnąc stan psychofizycznego odprężenia:

Hydroksyzyna na mnie bardzo fajnie działa, więc... ona i z taką herbatką Nervosol Herbapolu bardzo dobrze na mnie wpływają, jak biorę sobie tę Hydroksyzynę i popijam sobie później tę herbatkę, z dwa kubeczki wypijam, wtedy naprawdę bardzo fajnie, człowiek taki fajny jest, tak wszystko puszcza... człowiek bardzo fajnie zasypia... [Sabina, 43]

Jest to indywidualnie opracowana formuła na poprawę snu. Można założyć, że środek ziołowy uczestniczy w całościowej terapii zaburzeń lękowych rozmówczyni, przy czym środkowi temu zostaje przyznana specjalna nisza, w której ma oddziaływać - nisza ta obejmuje uśmierzanie, wespół z przepisaną przez psychiatrę Hydroksyzyną, problemów Sabiny [43] ze snem ${ }^{19}$. W nieco podobny sposób, łącząc rożne środki, postępowała inna rozmówczyni, Wiktoria [23], cierpiąca na silne lęki agorafobiczne ( $w$ związku $\mathrm{z}$ tym przez długi czas miała problemy $\mathrm{z}$ opuszczeniem domu) oraz lęki na tle możliwego zachorowania na chorobę przewlekłą. Z jej relacji wynika, że nie pomogła jej ani psychoterapia, ani „sama” farmakoterapia. Dlatego być może Wiktoria celem poprawy samopoczucia przez

19 O niszy oraz praktykach technonaukowych piszą również Adele Clarke ze współpracowniczkami (2003: 181), jednak moja konceptualizacja powstała przed lekturą tekstu autorek. 
pewien czas łączyła przepisany jej przez lekarza rodzinnego Bellergot z różnego rodzaju substancjami ziołowymi:

zawsze przekraczałam zalecaną dawkę [...], jadłam dziennie około 4-5 tabletek, więc no w końcu mnie nużyło i spałam, ale ja to też mieszałam z innymi preparatami, takimi ziołowymi, no bo żeby jakby, to ten efekt podnieść, tak? Bo ktoś mi ze znajomych polecił, no to zaraz biegłam do apteki i kupowałam... Strasznie mieszałam te leki.

Dawki leku określone przez lekarza okazują się niewystarczające z perspektywy pacjentki (stad praktyka „swobodnego dawkowania”). Można powiedzieć, że moja rozmówczyni, mając do dyspozycji leki przepisane od lekarki oraz ogólnodostępne środki ziołowe, stara się, za każdym razem, opracować nowy, spełniający jej potrzeby medykament i przez to intensyfikować proces leczenia. Takie łączenie „twardych” leków na receptę z łagodniej działającymi („miękkimi”) środkami pochodzenia ziołowego również można wpisać w kontekst sprawczości, w szerszym zakresie mieści się ono również w ramach procesów biomedykalizacji (Clarke et al., 2003: 179). W obu przywołanych przypadkach następuje fuzja substancji ziołowego pochodzenia oraz leków dostępnych na receptę, fuzja, która ma wygenerować efekty pożądane przez obie rozmówczynie: pojedyncza substancja (sam środek ziołowy lub sam lek psychotropowy) okazuje się niewystarczająca, konieczne jest ich połączenie. Tak manifestujące się współistnienie dwóch form leczenia jest tutaj, jak można sądzić, odpowiedzią na niewiarę w samodzielnie działającą etno- oraz biomedycynę.

\section{Praktyka trzecia: trzymanie leku przy sobie}

Związane z lekami praktyki, o których mi opowiadano $\mathrm{w}$ trakcie przeprowadzanych wywiadów, przybierały jednak także i inną postać. Część osób, z którymi rozmawiałem, wskazywała, że nie muszą wcale przyjmować przepisanych medykamentów - wystarczyło im, że noszą listki tabletek przy sobie (dotyczyło to jednak wyłącznie leków benzodiazepinowych lub uspokajających). Tak właśnie było w przypadku Moniki [32], która przez dość długi czas nosiła w torebce otrzymany od przyjaciółki listek Hydroksyzyny, ani razu jednak nie sięgając po ten lek. Jak konstatowała: „mam ten listek jako takie koło ratunkowe, którego nie używam. Ale lubię mieć to poczucie, że on tam jest”. Wystarczające jest więc posiadanie leku, nie zaś jego konsumpcja. Niestandardowy sposób otrzymania leku (od przyjaciółki) łączy się tutaj z niestandardowym sposobem jego użytkowania. Dla takich osób jak Monika medykament stał się więc czymś w rodzaju osobistego apotropeionu. Podobnie postępowali także inni rozmówcy, trzymający przepisane środki psychotropowe w domach, bez ich użytkowania, a także rozmówczyni przechowująca w lodówce uspokajający preparat ziołowy Validol - jak wskazywała wzmiankowana osoba: „mi wystarczy sama świadomość, że to mam” [Maja, 
35]. Także przywoływana wcześniej Joanna [43] przechowywała lek Lexotam do momentu, aż stracił on ważność, jednak bez jego zażywania:

Lexotam do całkiem niedawna miałam na półce jeszcze u siebie, z tym że on leżał... był takim zabezpieczeniem dla mnie, w razie czego, tak? Ale go po prostu nie zażywałam... ale wiedziałam, że w razie czego, w razie krytycznej sytuacji on jest [Joanna, 43].

Dla cytowanej osoby lek jest również formą „koła ratunkowego”: czymś, co pozostaje w rezerwie, z czego jednostka może skorzystać w każdej chwili (jednak nigdy do tego nie dochodzi). Można mówić o praktyce trzymania w pobliżu leków psychotropowych, która - chociaż nieprzewidywana w ramach leczenia biomedycznego, generowała określone implikacje dla samopoczucia ${ }^{20}$ - niczym rytuał prokurujący konkretne rezultaty dla przechodzącego go podmiotu (Douglas 2007: 96, 106-107). Mamy zatem do czynienia z, by tak to ująć, farmakoterapią bez farmakoterapii, działaniem zbliżonym do działania placebo - chociaż $\mathrm{w}$ omawianym przypadku, odwrotnie niż w przypadku placebo, wykupuje się prawdziwe leki. Paradoksalnie w takich przypadkach konieczna jest więc wizyta u lekarza - by wypisał dany lek - niekonieczne zaś jest faktyczne rozpoczynanie farmakoterapii. Trzymanie leków uspokajających w pobliżu bez ich zażywania przynosi pewien efekt dla psychiki pacjentów, a w świetle artykułowanych przez rozmówców obaw o możliwe uzależnienie od środków uspokajających jest to, być może, optymalny sposób na korzystanie ze wzmiankowanych środków. Wykupywanie leku bez jego przyjmowania sprawia też, że dany medykament „wystarcza” na zdecydowanie dłuższy czas w porównaniu do sytuacji zażywania leku. Granicą „korzystania” z leku nie jest w takiej sytuacji liczba tabletek, ale raczej data ważności danego medykamentu - przynajmniej w przypadku Joanny. Nazwa, jaką chciałbym opatrzeć tę praktykę, to: „farmakoterapia niekonsumowana”.

\section{Przed zakończeniem: leki nie tylko od psychiatry}

Warto w tej części tekstu, zanim przejdę do końcowego fragmentu, dodać, że leki antydepresyjne i uspokajające przepisywane były moim rozmówcom nie tylko przez psychiatrów, ale również przez lekarzy rodzinnych. Jako przykład można podać medykament Asentra, przepisany Żanecie [31], cierpiącej na nagłe ataki paniki (tzw. lęk napadowy) przez jej lekarkę pierwszego kontaktu. W przypadku innej osoby wybór lekarki rodzinnej pozwolił znacząco zredukować całościowe koszty leczenia farmakologicznego, usuwając z kuracji (co dotyczyło także kilku innych osób otrzymujących środki psychotropowe od lekarzy rodzinnych) ele-

20 Z kolei Jerzy Wasilewski, obserwując symboliczno-rytualne praktyki mieszkańców mongolskiej jurty, odnotowywał, że niektóre z owych praktyk, jakkolwiek performowane z podziwu godną regularnością, są przeważnie traktowane jako rytuał, za którym nie idą żadne doniosłe implikacje (Wasilewski 1977: 108-109). 
ment kontroli ze strony psychiatrii (zob. Rose 2006), lecz nie ze strony biomedycyny w ogóle. Jak konstatowała wzmiankowana osoba:

już pytałam mojego lekarza rodzinnego, czy jak mi się teraz skończy [Elicea], czy może mi wystawić receptę, żebym nie szła do psychiatry płacić tyle pieniędzy, jeszcze potem za leki [...] Przynajmniej nie zapłacę za wizytę u psychiatry [Monika, 28].

Tutaj ujawnia się praktyka wyboru podmiotu, który ma wydać pacjentce określony medykament: po raz pierwszy lek przepisał psychiatra, kolejny raz ma to zrobić lekarka rodzinna. Lek został więc przez pacjentkę sprawdzony i zaaprobowany, teraz trzeba tylko dobrać najefektywniejszą ekonomicznie drogę do jego pozyskania. Należy zaznaczyć, że rozmówczyni miała negatywne doświadczenia Z wizyt u lekarzy psychiatrów, co również mogło wpłynąć na jej nastawienie względem kolejnych wizyt psychiatrycznych; na kwestie ekonomiczne nakłada się więc personalna niechęć do tej kategorii lekarzy. Tak więc w tym przypadku mamy do czynienia ze specyficznym nastawieniem pacjentki; leki psychotropowe tak, kontakt z psychiatrą - nie: w taki sposób można podsumować wypracowaną przez Monikę [28] wizję leczenia trapiącego ją zaburzenia lękowego. Jest to „farmakoterapia odpsychiatryzowana”. Ogólnie jednak leki przepisywane moim rozmówcom przez lekarzy rodzinnych były traktowane analogicznie jak te ordynowane przez psychiatrów.

\section{Opór i przepowiednia: kilka słów na koniec}

Nie każda osoba z zaburzeniami lękowymi, która zgodziła się na udzielenie mi wywiadu, deklarowała podejmowanie praktyk, jakie zostały opisane powyżej były wśród moich rozmówców jednostki, które przyjmowały przepisane im leki w trybie zaleconym przez lekarza. Taką osobą był na przykład Hubert [18], który łącznie bierze aż trzy medykamenty w związku z fobią społeczną i depresją: Paxtin, Absenor oraz doraźnie Chlorprotiksen; dodatkowo uczęszczał również na psychoterapię. W toku wywiadu nie wynikało, by na przykład podejmował on decyzję o tym, aby nie przyjmować jednego przepisanego leku lub przyjmować go w mniejszej dawce lub nosić któryś z sobą bez konieczności zażywania go. Takich pacjentów na pewno mogliby sobie życzyć lekarze psychiatrzy. O przemodelowywaniu terapii lekami wspominano mi jednak niezwykle często, przy czym częściej dotyczyło to leków benzodiazepinowych (uspokajających) niż antydepresyjnych jakkolwiek zdarzało się również w odniesieniu do tych ostatnich. Podsumowując zawartość niniejszego artykułu, można zaznaczyć, że to, jakie leki zasugeruje osobom (przynajmniej tym z zaburzeniami lękowymi) lekarz i w jakich dawkach, ulec może zmianom w praktykach podejmowanych przez pacjentów (de Certeau 2008). Praktyki te ukazują, że rzeczywisty przebieg farmakoterapii może odbiegać od modelowego obrazu wzmiankowanej formy leczenia - w myśl którego lekarz 
przepisuje pacjentowi leki oraz instruuje o szczegółach ich dawkowania, a pacjent dokonuje zakupu przepisanych środków i rozpoczyna ich konsumpcję zgodnie ze wskazówkami medyka.

W szerszym zakresie można je także odczytywać jako emanację zjawiska oporu (resistance) wobec biomedycyny w jej wydaniu psychiatrycznym, który to opór sprzyjać ma między innymi krystalizowaniu się „poglądów na właściwy poziom interwencji biomedycznej” oraz „dyskursów artykułujących ideę, że «więcej biomedycyny nie znaczy lepiej»" (Clarke et al. red. 2010: 14-15; zob. Nowakowski 2013: 228-233). Gdy przyjrzeć się praktykom rozmówców, to oscylują one wokół zmniejszenia liczby leków psychotropowych wprowadzanych do organizmu (praktyka „selektywnej farmakologizacji” oraz praktyka rytualnego trzymania leków przy sobie bez ich zażywania, którą określiłem mianem „farmakoterapia niekonsumowana") ${ }^{21}$. Takie praktyki można z jednej strony traktować jako pokłosie ogólnej opinii o lekach psychotropowych wśród moich interlokutorów: skoro medykamenty nie są w stanie wyleczyć zaburzeń lękowych, nie należy specjalnie na nich polegać. $Z$ drugiej jednak strony, jeżeli nie wierzy się w lecznicze właściwości leków i podejmuje praktyki w rodzaju „selektywnej farmakologizacji” czy „swobodnego dawkowania”, wówczas rzeczywiście efekt leczniczy może być odmienny niż zakładany w toku wizyt u psychiatry. Może tutaj zachodzić coś, co za Robertem Mertonem (2002) należałoby określić mianem „samospełniającej się przepowiedni” (farmakologicznej): dana osoba nie dowierza w skuteczność leków, przyjmuje je w formie zmodyfikowanej względem zaleceń psychiatry, a w rezultacie tego następuje ziszczenie się jej początkowych przekonań.

$\mathrm{Na}$ ile cała farmakoterapia pozwala na istnienie takich albo analogicznych praktyk, jak opisane wyżej, pozostaje kwestią otwartą. Być może użyteczne byłoby zbadanie interakcji i praktyk związanych z lekami wśród osób przyjmujących medykamenty przepisywane im na przykład przez kardiologów lub lekarzy chorób wewnętrznych albo wśród pacjentów konsumujących dostępne w każdym domu tabletki na ból głowy. Bez wątpienia etnografia farmakoterapii może być tak samo fascynującym obszarem badań jak etnografia nowotworów czy etnografia technologii reprodukcyjnych.

${ }^{21}$ Hubert Wierciński (2010 b) pisał, że także w przypadku chemioterapii stosuje się pewne dawki, które mają być na tyle silne, że usuną nowotwór, jednak na tyle słabe, że nie zabiją pacjenta. W takim wypadku decyzje podejmują jednak lekarze; jest ona zatem nieporównywalna z sytuacją, gdy to pacjent sam dokonuje pewnych ograniczeń w konsumpcji leków psychotropowych. 


\section{Bibliografia}

Abriszewski K.

2007 Teoria Aktora-Sieci Bruno Latoura, „Teksty Drugie”, nr 1-2.

Ahearn L.

2000 Agency, „Journal of Linguistic Anthropology”, nr 9.

Baer $\mathrm{H}$.

2004 Medical Pluralism [w:] C. Ember, M. Ember (ed.), Encyclopedia of Medical Anthropology, New York-Boston-Dordrecht-London-Moscow.

Certeau de $\mathrm{M}$.

2008 Wynaleźć codzienność. Sztuki działania, przeł. K. Thiel-Jańczuk, Kraków.

Chowaniec-Rylke A.

2018 „LCHAD Poland” - Role of the Internet in Case of a Rare Disease, w druku.

Cichocki P.

2012 Sieć przyjaciót. Serwis społecznościowy oczami etnografa, Warszawa.

Clarke A. et al.

2003 Biomedicalization: Technoscientific Transformation of Health and Illness and U.S.

Biomedicine, „Sociological Review”, nr 2.

Clarke A. et al. (ed.),

2010 Biomedicalization: Technoscience, Health and Illness in the U.S., Durham.

Cohen C.

1993 The Biomedicalization of Psychiatry: A Critical Overviev, „Community Mental Health Journal", nr 6.

Conrad P.

2005 The Shifting Engines of Medicalization, „Journal of Health and Social Behavior”, nr 45.

Cujipers P. i in.

2013 The Efficacy of Psychotherapy and Pharmacotherapy in Treating Depressive and Anxiety Disorders: A Meta-analysis of Direct Comparisons, „World Psychiatry”, nr 12.

Cujipers P. i in.

2014 Adding Psychotherapy to Antidepressant Medication in Depression and Anxiety Disorders: A Meta-analysis, „World Psychiatry”, nr 13.

Czyżewski M.

2008 Elementy i całości. O niektórych dylematach analizy dyskursu [w:] A. Horolets (red.), Analiza dyskursu w socjologii i dla socjologii, Torun.

Douglas M.

2007 Czystość i zmaza, przeł. M. Bucholc, Warszawa.

Ecks S.

2005 Pharmaceutical Citizenship: Antidepressant Marketing and the Promise of Demarginalization in India, „Anthropology and Medicine”, nr 2.

Ecks S., Basu S.

2014 „We Always Live in Fear”: Antidepressant Prescriptions by Unlicensed Doctors in India, „Cult Med Psychiatry”, nr 38.

Frank A.

2005 The Remission Society [w:] Peter Conrad (ed.), The Sociology of Health and Illness: Critical Perspectives, New York. 


\section{Haggett A.}

2009 Desperate Housewives and the Domestic Environment in Post-war Britain: Individual Perspectives, „Oral Hist (Colch)”, nr 37(1).

Kockelman P.

2007 Agency. The Relation between Meaning, Power and Knowledge, „Current Anthropology", nr 3.

Kościańska A.

2009 Potega ciszy. Konwersja a rekonstrukcja porzadku płci na przykładzie nowego ruchu religijnego Brahma Kumaris, Warszawa.

Kozinets R.

2012 Netnografia. Badania etnograficzne online, tłum. M. Brzozowska-Brywczyńska, Warszawa.

Lakoff A.

2004 The Anxieties of Globalization: Antidepressant Sales and Economic Crisis in Argentina, „Social Studies of Science”, nr 2.

Marshall G. (red.),

2005 Słownik socjologii i nauk społecznych, M. Tabin [red. polskiego wydania], Warszawa.

Martin E.

2006 The Pharmaceutical Person, „Biosocieties”, nr 1.

Merton R.

2002 Teoria socjologiczna i struktura społeczna, przeł. J. Wertenstein-Żuławski, E. Morawska, Warszawa.

Metzl J.

2003 Prozac on the Couch: Prescribing Gender in the Era of Wonder Drugs, DurhamLondon.

Ngai $P$.

2010 Pracownice chińskich fabryk, tłum. E. Charkiewicz, Poznań.

Nowakowski M.

2013 Medykalizacja we współczesnych społeczeństwach Zachodu. Studium literatury przedmiotu, niepublikowana praca doktorska obroniona na Uniwersytecie Marii Curie-Skłodowskiej, Lublin.

Penkala-Gawęcka D.

2010 Pluralizm medyczny w perspektywie antropologicznej [w:] D. Penkala-Gawęcka (red.), Nie czas chorować? Zdrowie, choroba i leczenie w perspektywie antropologii medycznej, Poznań.

Popper K.

1999 Przewidywania i proroctwa w naukach społecznych [w:] K. Popper, Droga do wiedzy. Domysły i refutacje, tłum. S. Amsterdamski, Warszawa.

Pużyński S.

1997 Leki psychotropowe i podstawowe zasady leczenia depresji, „Postępy Psychiatrii i Neurologii", nr 6.

Rakowski T.

2009 Łowcy, zbieracze, praktycy niemocy. Etnografia człowieka zdegradowanego, Warszawa.

Rose N.

2006 Disorders without Borders? The Expanding Scope of Psychiatric Practice, „Biosocieties", nr 1. 
Schilling Ch.

2008 Kultura, „rola chorego” i konsumpcja zdrowia [w:] M. Bogunia-Borowska, P. Sztompka [red.], Socjologia codzienności, Kraków.

Seligman M., Walker E., Rosenham D.

2003 Psychopatologia, tłum. J. Gilewicz, A. Wojciechowski, Warszawa.

Wasilewski J.S.

1977 Symboliczne uniwersum jurty mongolskiej, „Etnografia Polska”, nr 21.

Wasilewski J., Wasilewska K.

2006 Retoryka pigułki, czyli o człowieku jako chemicznej maszynerii [w:] M. Marcjanik (red.), Retoryka codzienności. Zwyczaje językowe współczesnych Polaków, Warszawa.

Wierciński H.

2010a Nowotwór i technika medyczna w narracjach „ocalonych” pacjentów - na przykładzie chemio- $i$ radioterapii [w:] D. Penkala-Gawęcka (red.), Nie czas chorować? Zdrowie, choroba i leczenie w perspektywie antropologii medycznej, Poznań.

Wierciński H.

2010b Historie czerwonych buteleczek. Chemioterapia jako technologia transgresyjna, http://opcit.pl/teksty/historie-czerwonych-buteleczek (dostęp: 10.01.2015). Wodak R.

2011 Wstęp: badania nad dyskursem - ważne pojęcia i terminy [w:] R. Wodak, M. Krzyżanowski (red.), Jakościowa analiza dyskursu $w$ naukach społecznych, przeł. D. Przepiórkowska, Warszawa, s. 11-48.

Wróblewski M.

2013 Wyzwanie biomedykalizacji. Socjologia medykalizacji oraz socjologia zdrowia i choroby „podszyte” teorią aktora-sieci, „Przegląd Kulturoznawczy”, nr 15. 